\title{
A Collaborative Framework For Foreign Aid Projects In Sub-Sahara Africa
}

David King, (E-mail: david.king@unisa.edu.au), University of South Australia, Australia

\begin{abstract}
This paper highlights the significance of local community participation in foreign aid projects. The focus of the paper is that aid projects in sub-Sahara Africa (SSA) need effective project management method. The importance of local communities participation in a collaborative monitoring environment is argued. The aim of the paper is to challenge existing practice, contribute to and discuss the pragmatics of local communities involvement in foreign aid projects. Moreover, the need for local communities' voice reaching the international arena is necessary. Surveys and interviews from an interpretive perspective were used as data collection methods to support the argument. The intellectual framework of this study suggests that stakeholder collaboration can improve foreign aid project management practices in sub-Sahara Africa.
\end{abstract}

\section{Introduction}

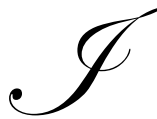

$\mathrm{n}$ this paper, the researcher argues that effective management of foreign aid projects in sub-Sahara Africa requires local community participation and stakeholder collaboration. It is believed that the framework and environment of managing aid projects has a huge influence on the outcome of project success, and therefore the involvement of Aid organisations (donors), national governments (recipients) and local communities (clients) is essential. Disintegration of stakeholders has been identified by King and Metcalfe (2002) as a contributor to aid project management failures in the region. The focus of the paper is therefore primarily on local community participation in foreign aid projects

The past and existing approaches to aid projects in sub-Sahara Africa have been a failure in relation to the region's socio-economic growth. This paper suggests a more collaborative, community based project management approach, which should deliver the alignment ideals of good aid project management. The aim is to improve the effectiveness of project team accountability through collaborative monitoring systems. The concept (see Fig. 1, 2, 3, and 4) in this paper was developed as the research fieldwork revealed its usefulness and highlighted the need for decisive consideration. The limited success of previous applications of guidelines and suggestions further supports the need for a revised concept.

The job of managing a project has been described since early times in terms of organisational skills and capacity for wide-ranging forethought (Yukl, 1981). This needs a wide range of local perspectives yet, too often, the less experienced local communities have been excluded from making a contribution. The lack of internal and external project team work and information openness during project definition and implementation is noteworthy. The objectives and the yardsticks (cost, schedules and performance) established at the time of project implementation need to formally recognise the need for local community participation. USAID (1993) witness that in the past, projects have inserted all reporting responsibilities to government bodies without local community involvement. Scott and Silva-Ochoa (2001) recognise that the involvement of the public and local government in the planning, implementation, and monitoring stages of project development may ensure that foreign aid is of greater benefit to its recipients (see Fig 1 for further explanation). 
Incorporate local community monitoring of project activities, both of an ongoing or expost nature.

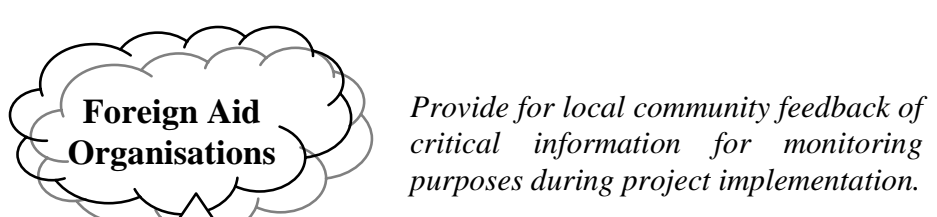

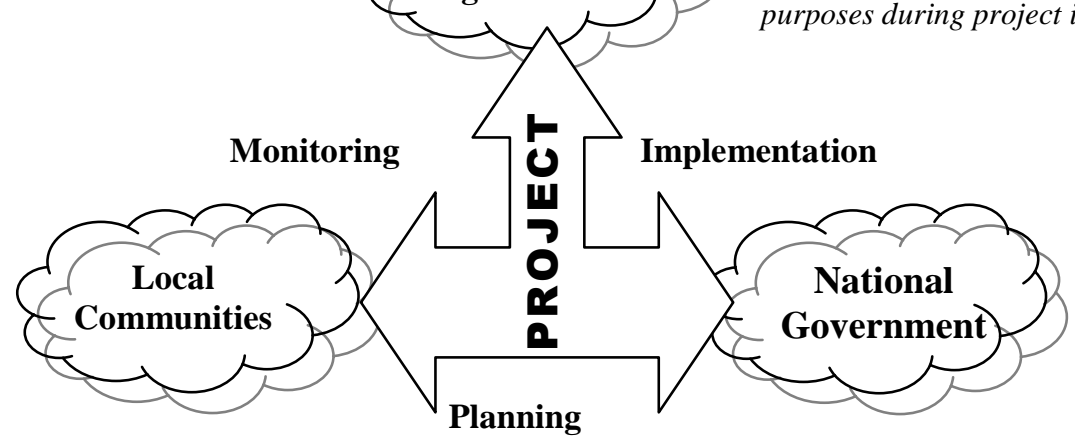

Management ensures that implementation at various levels of the project hierarchy proceeds according to plan.

Figure 1: Tripartite Management System

Project 'implementation' should include specification of steps and procedures required to assist in future planning and decision making. Foreign aid projects need extensive collaborative monitoring as proposed in Fig. 1 to identify errors or drawbacks of aid projects and overcome anticipated problems (Douglas and Lawrence, 1997). The old proverb 'many hands make light work' can be applied to aid projects as this increases the number of eyes and ears on the job. In the stages described in Fig. 1, the researcher recognises the need for foreign aid organisations to 'lead the way' in project implementation, management, and monitoring but that all parties (i.e. foreign aid institutions, national governments and local communities) must be sincere to one another, through collaborative participation, for the success of each stage of aid project implementation. Allen et al. (1998) recognise the need for foreign aid organisations to draw upon the knowledge of local communities, suggesting that all parties be involved in project 'management' as this guarantees a broad knowledge base for devising a plan. Foreign aid organisations could take responsibility for initiating the involvement of the national government and local communities to allow for sustainable management systems.

\section{Aid Projects And Problems}

Although some individual development projects have worked, and humanitarian aid can help alleviate the effects of crises, there is little evidence that official cash transfers, whether bilateral or multilateral, actually help advance growth or bring about stability in the sub-Saharan region (World Bank, 1996). Findings from an OECD (1998) report indicate that, in the era between the ending of World War II and late 1990s, the United States alone distributed more than $\$ 1$ trillion dollars in bilateral assistance internationally. In addition to this, other nations have provided hundreds of billions of dollars (see Table 1 for details of Aid distribution as example between 1971-1994). This could be directly or through U.S. funded multilateral institutions (e.g. the International Monetary Fund, the World Bank, and the United Nations). 


\begin{tabular}{|c|c|c|c|c|c|c|c|}
\hline \multicolumn{8}{|c|}{$\begin{array}{c}\text { Table 1 } \\
\text { Aid, 1971-1994 (millions of nominal dollars) }\end{array}$} \\
\hline $\begin{array}{l}\text { Recipient } \\
\text { Nation }\end{array}$ & $\overline{\text { U.S. Aid }}$ & $\begin{array}{c}\text { Total } \\
\text { International } \\
\text { Aid }\end{array}$ & $\begin{array}{l}\text { Annual } \\
\text { Average }\end{array}$ & $\begin{array}{l}\text { Recipient } \\
\text { Nation }\end{array}$ & U.S. Aid & $\begin{array}{c}\text { Total } \\
\text { International } \\
\text { Aid }\end{array}$ & $\begin{array}{l}\text { Annual } \\
\text { Average }\end{array}$ \\
\hline Angola & 117 & 2865.8 & 119.4 & Sierra Leone & 172 & 1770.6 & 73.8 \\
\hline Burundi & 139 & 3354.2 & 139.8 & Somalia & 1591 & 6212.6 & 310.6 \\
\hline Chad & 239 & 3281.6 & 136.7 & Sri Lanka & 1076 & 9808.7 & 408.7 \\
\hline Ethiopia & 999 & 11528.6 & 480.4 & Sudan & 1676 & 13419.3 & 559.1 \\
\hline Haiti & 1425 & 3120.7 & 130.0 & Uganda & 295 & 5798.8 & 241.6 \\
\hline Liberia & 639 & 1795.0 & 74.8 & *Yugoslavia & -291 & 529.9 & 25.2 \\
\hline Mozambique & 625 & 10465.7 & 436.0 & Zaire & 529 & 8416.6 & 350.7 \\
\hline Rwanda & 416 & 4660.0 & 194.2 & & & & \\
\hline
\end{tabular}

Source: Bandow, D. (1997) Help or Hindrance: Can Foreign Aid Prevent International Crises? Cato Policy Analysis No. 273, April 25, 1997.

*Data through 1991, including aid flows through 1994 to the states that made up the former Yugoslavia, total U.S. aid amounts to $-\$ 250$ million, total international aid amounts to $\$ 6.1$ billion, and the annual average is $\$ 253.6$ million.

According to Boone (1995) "aid does not promote economic development for two reasons: Poverty is not caused by capital shortage, and it is not optimal for politicians to amend policies and procedures when they receive aid flows." Only a handful of countries that started receiving U.S. assistance in the 1950s and 1960s ever graduated from dependent status, likewise, a number of countries have been on international aid organisations and International Monetary Fund programs for many decades (Bandow, 1994), and have in general failed to grow economically. In many instances, the so-called 'aid' has proven to be positively destructive, financing sadistic dictators as they have invaded their citizens (Atwood, 1996). On other occasions, Western aid subsidies have financed the creation of inefficient state-led development programs. As Bandow (1995) stated, the US and other sources of aid have supported governments that were both dishonest, corrupt and collectivist.

Numerous advocates of continued foreign assistance acknowledge the unsatisfactory results of past procedures. For example, in 1993, the US Agency for International Development (USAID, 1993) admitted that much of the investment funded by their agency and other Western donors in the period of 1960 and 1980 disappeared without a trace. Overall, aid levels do not correlate positively with economic growth, and many of the recipients of foreign assistance, have been among the globe's worst economic players (Atwood, 1996). Yet, a positive correlation would not be enough to prove that aid actually achieves its purpose, the real issue is causation, and there is no evidence that aid generates growth.

\section{Economic Freedom and Local Community Participation}

In the mid 90's the results of the 1996 Index of Economic Freedom demonstrated that "economic freedom is the single most important factor in creating the conditions for economic growth and prosperity," Johnson and Sheehy (1996) found that such factors as access to knowledge and capital could not explain the relative income differences among nations. Olson Jr. (1996) stated "The only remaining plausible explanation is that the great differences in the wealth of nations are mainly due to differences in the quality of their institutions and economic policies", he found that poorer nations with the best economic policies consistently grew the fastest. Failures in the sub-Sahara regions are found to be in various forms, from leadership cruelty to freedom monopoly (World Bank, 1996). This can be a lesson to sub-Sahara African leaders not wanting a change in attitude and management. The prevailing of individual freedom and participation, for example voting systems (TV opinion poll and surveys) is a sign of local community participation for sound economy and coherence of a nation.

Weinberger and Jütting (2001) recognise the importance of civil society participation in economic and political functionality. Based on Weinberger and Jütting's (2001) Three Spheres of an Economy framework it is proposed that countries, which introduce and allow local community participation and project collaboration in decision making may have a better chance for economic freedom (see Figure 2). 


\section{CURRENT STRUCTURE}

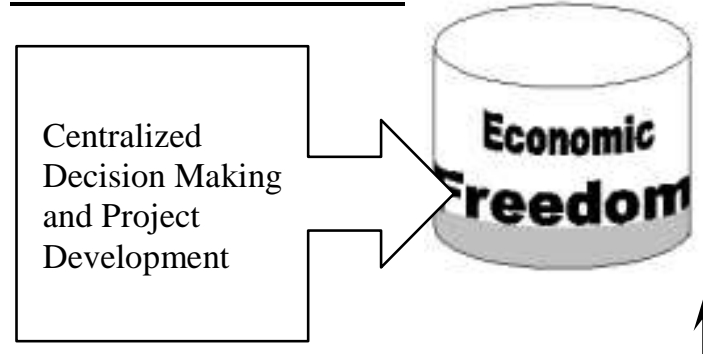

Penalises Individual Initiative Discourages Saving and Investment Restricts the Operation of Free Market

\section{SUGGESTED CONCEPT}

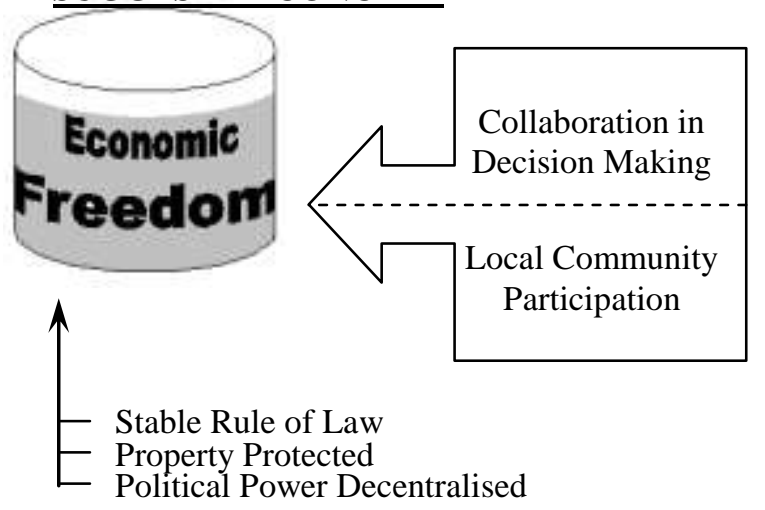

Figure 2: Attributes Affecting Progress of Economic Freedom (Adapted from Osterfeld, 1992)

Osterfeld (1992) reviewed the economic impact of a range of variables: corruption, food, foreign aid, migration, multinational corporations, population, and resources. His conclusion was that development occurred most quickly in an "enabling environment" in which the rule of law was stable, property was protected, and political power was decentralized. Sustained economic development is possible explains Osterfeld (1992) "the principal obstacle is an environment that penalizes individual initiative, discourages saving and investment, and severely restricts the operation of free market". Thus, development will not occur in the absence of radical changes in the existing foreign aid frameworks that still serve as a socio-economic guide for most of the countries in the so-called Third World (Malpass, 1999).

\section{Change Of Practice And Empowering Local Communities}

Osterfeld's (1992) work suggests that constructive aid project changes can only happen and be sustained if the local communities effected are included and empowered to make decisions. People's participation, the integration of the efforts of institutions and improved flows of information are indispensable to the building of real and lasting capacity for sustainable human development (UNDP, 1996b). The failure of foreign aid to meet its traditional goals has led to a search for new justifications, the fact that for years foreign aid subsidized authoritarian and collectivist governments (Bandow, 1995), is reason enough to consider a more community-based approach in future. This empowering of local communities will hopefully enable the 'clients' of foreign aid to have a direct say in how a development project can best fulfil the communities' requirements.

Stame (1999) recommends taking into consideration the viewpoints of the different aid project stakeholders in relation to both the methodology as well as the content of the assessment, while Kuhlmann (1998) stressed how the various interests and perceptions of stakeholders will have direct effect on the outcome. In sub-Sahara Africa these approaches may be particularly conducive to aid project success as they empower the local communities to be collaboratively involved in project activities.

In sub-Sahara Africa, many governments simply are not interested in a prosperous administration and change of practice, some of them want their countries to develop but are unwilling to pay the political price for adopting the changes necessary to do so (Bandow, 1996). In sub-Sahara regions many governments are simply more interested in staying in power, than in achieving growth (Kpundeh, 1995). Indeed, change of practice and domestic policies, not only foreign aid, are what generate economic growth (Bandow, 1996). In the end, poor countries are largely responsible for their own destinies. One need not be a reflexive critic of sub-Sahara Africa governments to recognize that such regimes are an impediment to development, as Carter (1995) concludes: 
"Third World states are neither the instruments of international capital nor of an indigenous bourgeoisie, but are rational actors who will industrialise their economies when practicable, but who often find it in their interests to be accomplices in the dependent development or even underdevelopment of their own economies."

(Carter, P.614)

King and Metcalfe (2002) point out that with change of practice, projects undertaken by foreign aid organizations may be of greater benefit to sub-Saharan countries and their citizens. Aid organizations would need to appoint a committee to review old management structures and administration, and to recommend necessary adjustments in order to facilitate decentralisation and local community empowerment (Allen et al., 1998). Change of practice is one way of truly empowering local communities, this change would need to (1) incorporate the suggested changes to periodic assessment (see Figure 3.4), (2) decentralise current management practices, and (3) allow for greater public participation in project development (Allen et al., 1998). A framework for achieving this can be summarised in the three areas in Table 2.

\section{Management Practice: Organization and Administration}

Give the national government the freedom to manage development and provide public services according to the needs of their constituents in the local communities. Local administration can implement development plans as well as budget and financial policy.

2. Decentralisation: Duties and Responsibilities

Hold the national government responsible for the development and conservation of aid resources in their local communities. National government then transfers appropriate functions (including public service delivery) as well as financial support to the local communities. An Institution set up for a new decentralized framework is needed (see Fig. 1, 2, 3, 4), for example government administration and laws at a national level whose function is to maintain established projects. At the local level, the ministries and departments may not be allowed to control resources and implement development activities. The public are to be appointed to conduct implementation tasks at the regional and local levels on project development.

\section{Local Community Participation}

A Policy indicating that people in local communities can monitor, control and oversee the results and performance of the local administration. It is the government's duty to promote local communities participation in conserving and protecting aid resources. Aid organisations may penalise any person including any public officials or organizations that fail to perform their authorized functions and breach community regulations.

Table 2: Adapted from Allen et al. (1998).

Through local communities' participation and involvement in planning and decision-making processes, a local authority with good local governance can be produced (Allen et al., 1998). Decentralizing decision making to the local level has become one of the most important development issues discussed over the past two decades as Douglas and Lawrence (1997) assert. It is widely recognized that decentralization will increase the efficiency and awareness of local government, this statement can be supported by the many questions that have been raised about the sustainability of a program and its projects that are mainly managed and implemented by the national government (Bosch et al., 1996).

Locally elected leaders know their constituents better than officials appointed from the central government, they can provide the public services that the local people need (Meinzen-Dick and Knox, 2001). Technically and physically, it is easier for local communities to hold local officials accountable for their performance state Bosch et al. (1996), however they also recognise that true and sustainable development takes place when the stakeholders of a community equally and democratically share ideas and visions, as well as participate and take responsibilities together to steer and implement development activities. Allen et al. (1998) recognise the need to establish a bottom- 
up, people-centred planning and community development approach that would create a sense of ownership as well as partnership in development.

\section{Participatory development and sustainability}

The emerging directions of which can be seen to be developing through integration of participatory research approaches have been addressed for almost a decade (Bosch et al., 1996; Dovers and Mobbs, 1997; Christensen et al., 1996; Allen et al., 1998). The World Bank (1996) defines participation as "a process through which stakeholders influence and share control over development initiatives and the decisions and resources which affect them". The framework that supports the efforts of development on the ground can come about through collaborative planning and action. The perspective in this respect is to elicit local responses to local problems, of which approach, the aid agencies also become genuine participants by learning from local community feedback.

UNDP (1996a) metaphorically used the term 'sustainable human development' to describe the very humancenteredness of sustainable development. Canada's International Development Research Centre (IDRC) VicePresident, Pierre Beemans (1996) suggested that development is "change that improves the conditions of human well-being so that people can exercise meaningful choices for their own benefit and that of society". The World Bank (1996) also talks about 'empowering the poor' to help them become 'clients' rather than 'beneficiaries'. Figure 3 outlines the significance of collaborative participation in the possibility of greater success.

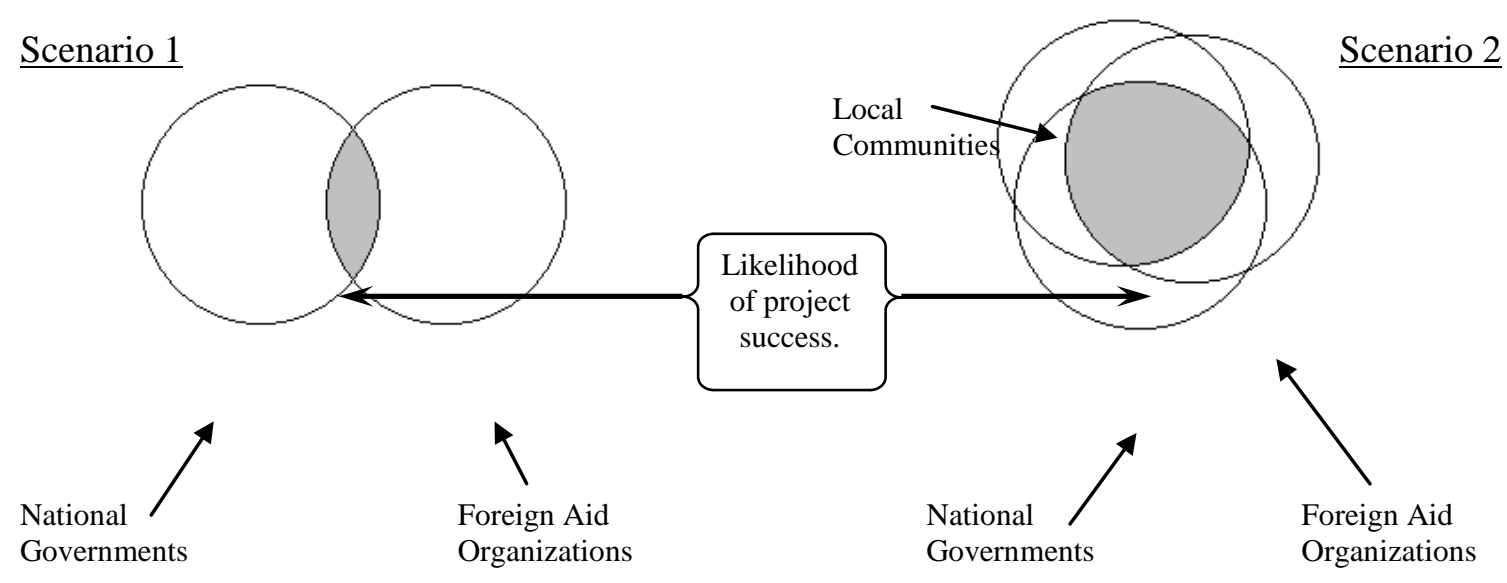

Figure 3: Collaborative Participation and Development

At present there is a very low level of project success in developing countries (Bandow, 1994), the researcher believes this is due to only two parties being involved (see Fig. 3, Scenario 1) in implementation, management and monitoring of aid projects. To increase the number of project successes in sub-Sahara regions we need to first achieve effective collaboration by allowing for local community participation on projects (see Fig. 3, Scenario 2).

\subsection{Activity- based collaborative learning}

Ledford and Mohrman (1993) point out that in large-scale action there is a need to develop a strategy for learning about loosely coupled activities that occur in multiple locations (e.g. the diversity of countries aid project's organisational needs in sub-Sahara Africa), increasingly in these situations, local communities will predominantly influence policy instruments, rather than management practice. Even in cases where local community or the public and government interests substantially coincide, collaborative learning can only work if individuals, and the wider 
community in which they operate, fully appreciate the nature of the problem involved, and their own self-interest in the matter. This, in turn, requires that such collaborative learning is supported by appropriate motivational, information and educational incentives. Similarly, these incentives invariably reinforce the effectiveness of collaborative frameworks as illustrated in Figure 4.

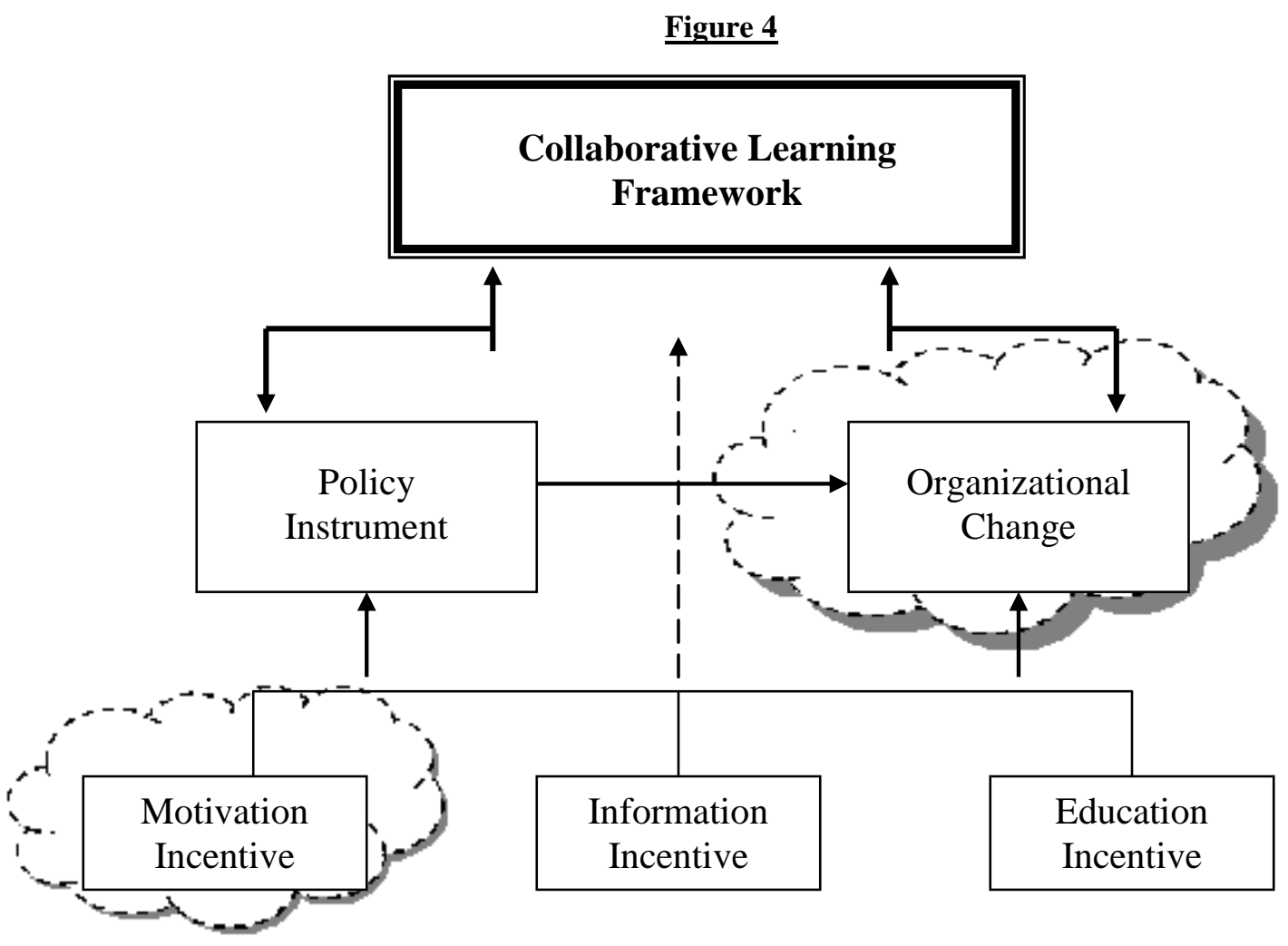

Figure 4 highlights the use of collaborative learning frameworks to support policy instruments and organisational change. This organizational change is also supported by appropriate policy instruments. Motivation, information and education are put at the bottom because of their major contribution to reinforcing and enhancing policy instruments and organisational change. If local communities are motivated and persuaded, that change is worthwhile, they are more likely to respond positively to other incentives (e.g. information and education). According to Allen et al. (1998) developing processes that build community ownership of decisions is one of the most effective ways to motivate people. Many contemporary research efforts are concentrating on creating new approaches to strategy in teamwork, as Jiggins (1993) points out, these efforts to use more collaborative project management methods, represent a search for research and development models and practices that combine the features of;

- $\quad$ management-based experimentation and innovation;

- $\quad$ people resource system management on scales larger than individual enterprises and communities;

- methods for bringing about capacity for action among multiple agencies and actors (with typically divergent points of view and interests); and

- facilitation of the social processes and organisational capacity. These research and development practices can accomplish information integration and participation. 


\subsection{Local communities and collaborative Decision making}

Beemans (1996) emphasizes that the significance of information, integration and participation are eminent prevailing frameworks that often include such dimensions as sustainable participatory governance, respect for human rights, gender equity and environmental practices. Though little has been done to give practical effect to the integration of local community's voice in decision-making, it is evident in UNDP (1997) that the conference in Rio emphasized integrated strategies to promote human development through economic growth based on sustainable management of local resources.

UNDP's (1996b) Capacity 21 Programme highlights that local community participation in collaborative decision-making is a fundamental prerequisite for achieving sustainable development. This programme identifies information, integration, and participation as key building blocks to help countries achieve development that recognizes these interacting factors. It emphasises that in sustainable development, everyone is a user and provider of information. It stresses the need to change from old ways of business engagement to new approaches that involve coordination and the integration of local community concerns into development, and collaborative decision-making processes. Within this framework a target outcome could be set out which may rise above specific local community interests and recognise shared national and international needs.

It follows that the task of organising information to understand better the links between project management and participatory dynamics should be a cooperative venture between aid organisations, local communities and national government. In this sense, collaborative approaches to project development and implementation are, in the first instance, about learning and reflection, and not only the provision of reports and the use of technologies. Where these participatory initiatives have worked, it is because individual communities and groups have seen the benefits of working collaboratively, of developing a collective vision, and learning and adapting their management practices together. However, despite the increasing numbers of participatory initiatives in different parts of the world, it is clear that the use of these practices is still a minority (Clayton et al., 1997).

In response to these issues both academics and practitioners are beginning to see increased interest in the application of more 'collaborative' processes that facilitate the wide involvement of individuals, groups and organisations in problem-solving and decision-making with respect to issues and plans that involve or have impact on them. This implies the institutionalisation of such initiatives and the corresponding capacity for activities to spread beyond the immediate project practices in both space and time. Moreover, in many of these participatory initiatives science has appeared to be by-passed. They are an approach to deal with 'soft systems', "in which objectives are hard to define, decision-making is uncertain, measures of performance are at best qualitative and human behaviour is irrational" (Checkland, 1981). As Pretty (1998) emphasises, true participatory projects are those which empower people by building skills, interests and capacities that continue even after the project ends.

\subsection{Collective Action}

Collective action is defined as people working together toward some common goal that brings about a potential solution (Meinzen-Dick and Knox, 2001). Understanding the nature and distribution of impacts to all stakeholders is especially important since these impacts have effect on people's willingness to participate and engage in collective action for aid project implementation. Collective action for management, according to Scott and SilvaOchoa (2001) is likely to be successful when it appeals to communities that are self-motivated to improve their lives and the welfare of their families.

There are different challenges and opportunities for collective action in countries like Uganda, Tanzania and Kenya. The governments of Uganda and Tanzania have already delegated significant authority to local government units (Shah and Raju, 2001). This puts governments in closer contact with local resource management problems and possibly improves their ability to implement management programs that bring together local policy makers, stakeholders, and technical agencies (Shah and Raju, 2001). As Swallow et. al. (2001) put it, "in the Kabale area of Uganda, for example, researchers, local policy makers and Non Government Officials (NGOs) have formed a research-policy forum for natural resource management". If indeed there are significant benefits to be gained from 
collective action at larger social scales, then there may be an important role for some credible external agency, for example sub-Sahara African expatriates and NGOs.

An important aspect of collaborative participation in project execution is that collective action elements of a programme are integrally linked with aid projects, and that the outcomes of stakeholder involvement can be fed into the successive activities and strategies. Besides, collective action approaches may provide a wider set of methodologies that can be made publicly available to both financial and non-financial aid organisations that undertake similar endeavours in other areas, and with other project issues.

\section{The Research}

The researcher supported his argument with interviewed and surveyed participants (mostly African communities) and to ensure in-depth results, cross-checked with diverse perspectives of nationals from all continents (Europe, North and South America, Asia and Australia). The researcher used Linestone's (1983) Multiple Perspectives as the basis for his interpretive research. The researcher conducted a survey involving approximately 150 participants from across four main areas (Academics, Practitioners, Undergraduates, and Postgraduates). Survey participants were asked to; (1) read a series of statements to which they had to indicate their level of agreement or disagreement, (2) rank a selection of possible answers in regards to their relevance to the corresponding assertions, and (3) give short answers to questions posed.

The researcher selected three core questions from the survey that underpin this particular investigation. The results for the responses to these questions are graphically represented below. They show a very clear trend in survey participant's responses towards Foreign Aid Spending (see survey question 1).

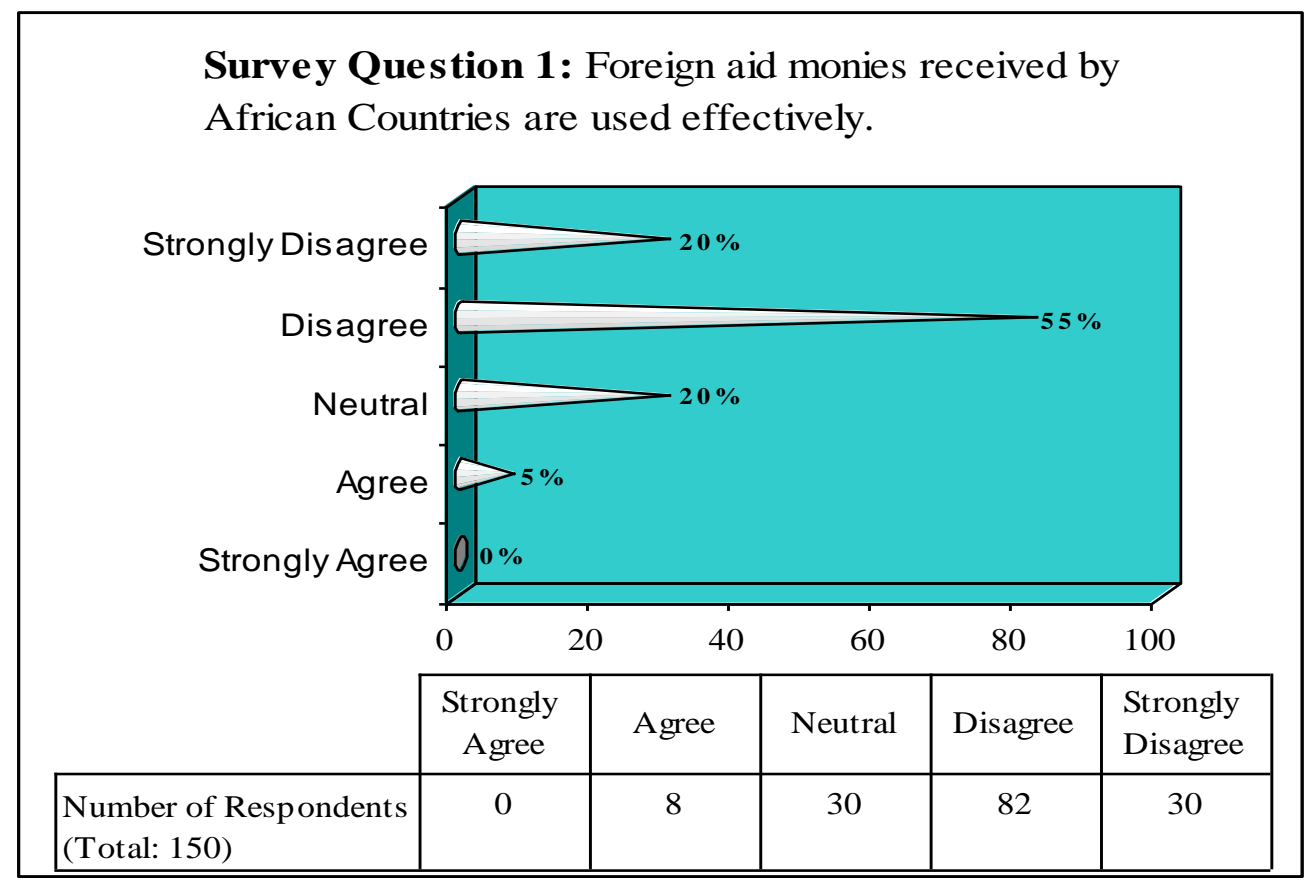

The outcome here showed that participants believed aid monies were not being spent effectively, this can be seen by the majority of survey responses disagreeing with the statement, with only about $5 \%$ agreement with this issue. Neutral responses were found to have come from participants that did not have any prior knowledge or interest in African foreign aid spending. Similar results were obtained from the researcher's interviews, when asked the same 
question, interview participants responded so passionately that they stood up and waved their fists in the air due to their frustration and anger, towards governments and foreign aid organisations, on this matter.

Responses to survey question 2 quite strongly pointed to the affirmative. Participants that already thought aid monies were being used effectively believed closer monitoring would further increase productivity of aid investment, while those respondents that had previously remained neutral, on the topic of African foreign aid spending, considered monitoring would improve any project. All participants believed that this monitoring should be carried out by the local communities.

The researcher also asked interview participants to provide information on who they believed should be responsible for the monitoring duties. The main response to this question was that the local communities, which are affected by aid project development, be given an avenue to monitor and report to foreign aid organisations. However, some concerns were raised about the achievability of such monitoring to be able to exclude government censorship, the response of one participant summed this up

“... as long as our government does not have anything to do with it. As long as they (government) do not set up the system, as long as a third party sets up the system, as long as it is free from any manipulation."

These statements were also added to, with interview respondents making clear their belief that, at present African citizens are not given enough information about foreign aid development.

“... we do not get any information until they (the government) have already got the money. We do not know why (for what purpose) they got the money or how much (foreign aid) they got. We can not make sure we get the money for what we were supposed to. When they (the government) tell us about it (foreign aid grants) they tell us we 'only got so much', when they actually get two or three times that amount."

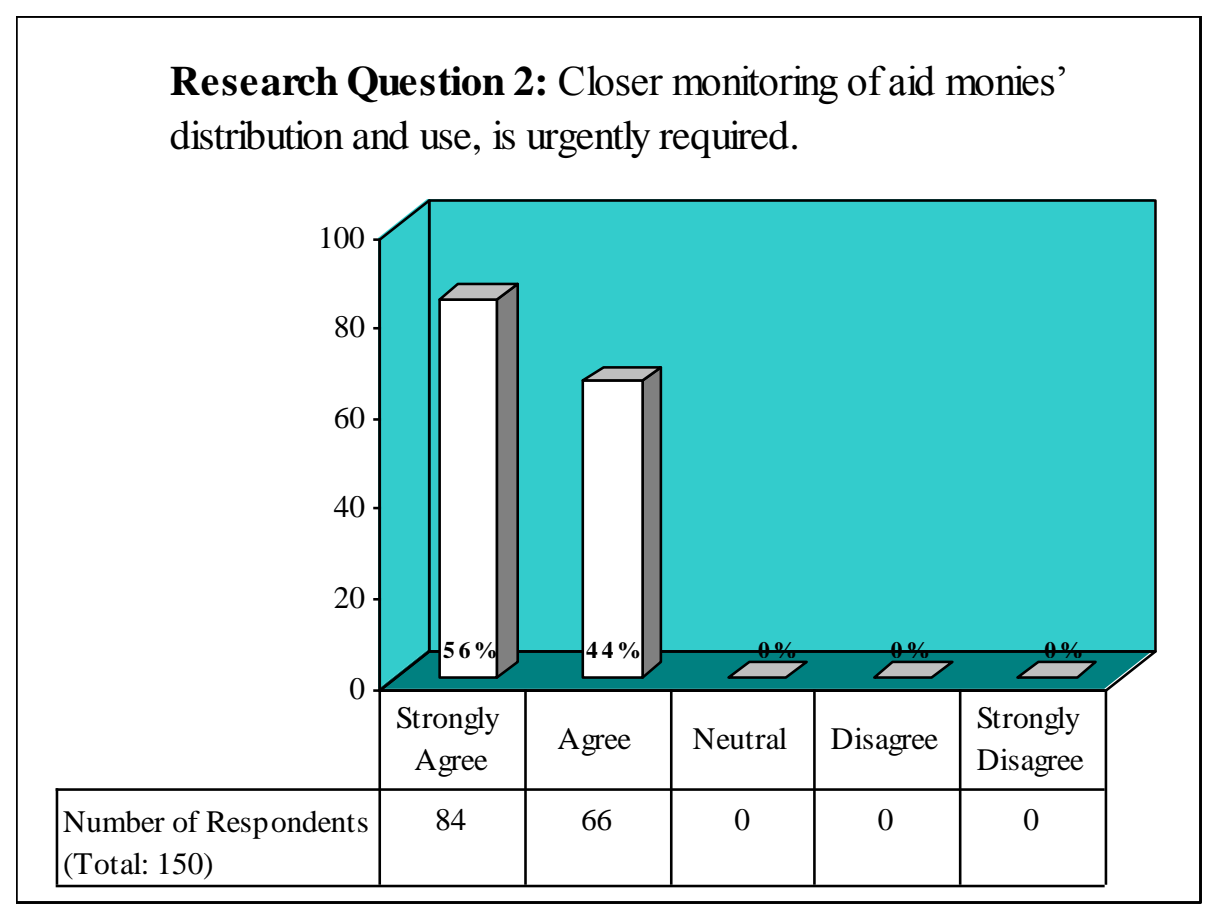


The frequency of responses such as these led the researcher to compose the following survey question.

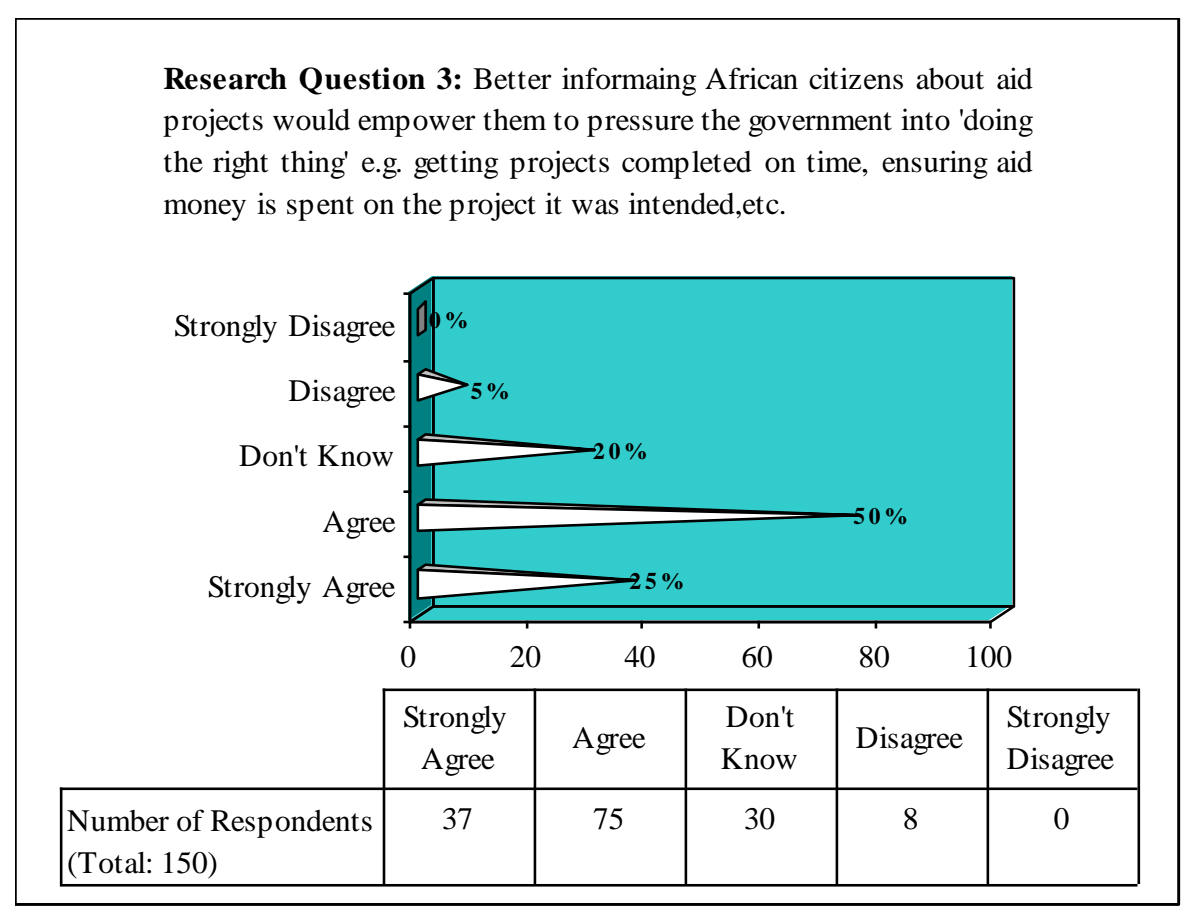

African citizens and foreigners alike generally believed that with more knowledge African citizens could improve the utilization of foreign aid monies. The researcher makes note of the correlation between results for survey question 1 and survey question 3, with neutral (don't know) responses again showing approx. 20\% (these responses were from respondents who have no, or very little, knowledge of African issues). The 5\% of survey responses that disagreed with this statement were also found to be the same $5 \%$ of participants that believed foreign aid monies were being spent effectively.

The researcher draws upon the survey results and interview responses to make the following conclusions. Generally participants viewed foreign aid monies very favourably in terms of potential usefulness, but were frustrated by the way in which they were being spent. Participants reported feelings of anger and disappointment, towards not only the African governments who allow, and are sometimes even involved in (Bandow, 1995) the misuse of funds, but also towards the foreign aid organisations themselves for not adequately monitoring and evaluating aid project development. They showed a significant desire to improve the quality of foreign aid spending, and believed that providing local communities with greater reliable information on aid projects, and the incorporation of local community monitoring and evaluation would greatly increase the pressure on all parties to "do the right thing' (i.e. make sure aid monies are spent entirely on the projects they were destined for, ensuring projects were completed on time, and also that quality work results from such spending).

\section{Conclusion And Suggestions}

This paper has suggested that foreign aid projects in sub-Sahara Africa must face the challenge of change and project structures must be clearly defined. It has been argued that only when local communities are given more control of foreign aid projects in sub-Sahara Africa, will socio-economic growth be achieved. Local communities can become empowered through collaboration and monitoring of foreign aid projects, when there are interactions between resource users, the resources themselves, and the institutions that govern their access, use and management. 
Local communities are likely to be able to predict with more accuracy the impact of foreign aid projects on such interactions. It is therefore imperative that local communities are involved in foreign aid project implementation.

The primary responsibility for development lies with sub-Sahara Africans. Governments in the region must create an economic environment in which people are free to be productive. The industrialized nations can help (primarily by doing no harm) by introducing good management that incorporates local communities. Foreign aid organisations should end government-to-government assistance, which has so often buttressed regimes dedicated to little more than maintaining power and eased the economic pressure for needed reforms. This study suggests that stakeholder collaboration can improve foreign aid project management practices in sub-Sahara Africa.

\section{References}

1. Allen, W.J., O.J.H. Bosch, R.G. Gibson, \& A.J. Jopp (1998) Co-learning our way to sustainability: An integrated and community-based research approach to support natural resource management decisionmaking, in Multiple objective decision making for land, water and environmental management, El-Swaify, S.A. \& Yakowitz, D.S. (Eds.) Lewis Publishers, Boston, USA.

2. $\quad$ Atwood, B. (1996) "Zaire: Reign of Error," Online Focus, December 26, 1996, transcript.

3. Bandow, D. (1994) "The IMF: A Record of Addiction and Failure," in Perpetuating Poverty, Bandow, D. and Vasquez, I. (Eds.) pp. 15-36.

4. Bandow, D. (1995) "A New Aid Policy for a New World," Cato Institute Policy Analysis no. 226, May 15, 1995.

5. Bandow, D. (1996) "Policy Reform: Necessary for Economic Growth and Poverty Reduction," Paper presented to Task Force on the United States and the Multilateral Development Banks, Center for Strategic and International Studies, Washington, July 22, 1996.

6. Bandow, D. (1997) "Help or Hindrance: Can Foreign Aid Prevent International Crises?" Cato Policy Analysis No. 273, April 25, 1997.

7. Beemans, P. (1996) "Culture, spirituality and economic development" in Culture, spirituality, and economic development: Opening a dialogue, Ryan, W.F. (Ed.) International Development Research Centre, Ottawa, Canada <http://www.idrc.ca/books/focus/782/782fore.html> Accessed 9 September, 2002.

8. Boone, P. (1995) "Politics and the Effectiveness of Foreign Aid Discussion" Paper No. 272, Centre for Economic Performance, December 1995.

9. $\quad$ Bosch, O.J.H., W.J. Allen, J.M. Williams \& A. Ensor (1996) "An integrated system for maximising community knowledge: Integrating community-based monitoring into the adaptive management process in The New Zealand high country", The Rangeland Journal 18, pp. 23-32.

http://www.landcare.cri.nz/science/social/index.shtml?monadman Accessed 4 October 2000.

10. Carter, A. (1995) "The Nation-State and Underdevelopment," Third World Quarterly, 16:4.

11. Christensen, N.L., A.M. Bartuska, J.H. Brown, S. Carpenter, C. D'Antonio, R. Francis, J.F. Franklin, J.A. MacMahon, R.F. Noss, D.J. Parsons, C.H. Peterson, M.G. Turner and R.G. Woodmansee (1996) "The report of the Ecological Society of America on the scientific basis for ecosystem management", The Ecological Society of America, Washington D.C. <http://esa.sdsc.edu/execsum.htm> Viewed 9 September, 2002.

12. Clayton, A., P. Oakley and B. Pratt (1997) "UNDP Guidebook on Participation, CSO and Participation Programme”, INTRAC, Oxford. http://www.undp.org/csopp/CSO/NewFiles/docemppeople.html Viewed 26 August, 2002.

13. Douglas, M. and P. Lawrence (1997) Planning Soil Conservation Projects Through Participation: A Guide, TDR Project R6570, Department For International Development (DFID), HR Wallingford Ltd., Howbery Park, Wallingford, October, 1997.

14. Dovers, C. and S. Mobbs (1997) "An alluring prospect? Ecology \& the requirements of adaptive management", in Frontiers in ecology, Klomp and Lunt (eds), Elsevier.

15. Jiggins, J. (1993) From technology transfer to resource management, in Grasslands for our world, Baker, M.J., (Ed.), SIR Publishing, Wellington, pp. 184-189.

16. Johnson, B. and T. Sheehy (1996) 1996 "Index of Economic Freedom”, Heritage Foundation, Washington. 
17. King, D. and M. Metcalfe (2002) "Using the Web for enhancing decisions: UN project failures in sub Sahara-Africa (SSA)", Pacific Asia Conference on Information Systems (PACIS), Tokyo, Japan, September 2-4, 2002.

18. Kpundeh, S. J. (1995) Politics and Corruption in Africa: A Case Study of Sierra Leone, University Press of America, Lanham.

19. Kuhlmann, S. (1998): "Moderation of Policy-Making? Science and Technology Policy Evaluation Beyond Impact Measurement-the Case of Germany", Evaluation, 4:2, SAGE Publications, London, Thousand Oaks and New Delhi, pp. 130-148.

20. Ledford, G.E. and S.A. Mohrman (1993) "Self-design for high involvement: A large-scale organizational change", Human Relations, 46(1), pp. 143-173.

21. Malpass, D. (1999) "Replacing the Vacuum in International Economic Policy", CATO Institute, paper presented at the 17th annual Monetary Conference: The Search for Global Monetary Order, <http://www.cato.org/realaudio/monconf17/malpass.html> Viewed online September 26, 2002

22. Meinzen-Dick, R.S., and A. Knox (2001) Collective action, property rights, and devolution of natural resource management: A conceptual framework, in Collective action, property rights, and devolution of natural resource management: Exchange of knowledge and implications for policy, Meinzen-Dick, R.S., A. Knox and M. Di Gregorio (Eds.), Zentralstelle für Ernährung und Landwirtschaft, Feldafing, Germany.

23. OECD (Organization for Economic Cooperation and Development) (1998), "Geographical Distribution of Financial Flows to Developing Countries", OECD, Paris.

24. Olson, M. (Jr.) (1996) "Big Bills Left on the Sidewalk: Why Some Nations Are Rich, and Others Poor," in Journal of Economic Perspectives, 10:2, spring 1996.

25. Osterfeld, D. (1992) Prosperity versus Planning: How Government Stifles Economic Growth, Oxford University Press, New York, 1992.

26. Pretty, J. (1998) "Participatory learning for integrated farming", in Proceedings of the Internet Conference on Integrated Biosystems, Long Foo, Eng \& Della Senta, T. (Eds.)

$<$ http://www.ias.unu.edu/proceedings/icibs/jules/paper.htm> Accessed 20 January 2000.

27. Scott, C.A. and P. Silva-Ochoa (2001) "Collective action for water harvesting irrigation in the LermaChapala Basin”, Mexico, Water Policy 36 (2001), pp. 555-572.

28. Shah, T. and V.K. Raju (2001) "Rethinking rehabilitation: socio-ecology of tanks in Rajasthan, north-west India”, Water Policy 36 (2001), pp. 521-536.

29. Stame, N. (1999) "Small and Medium Enterprise Aid Programs: Intangible Effects and Evaluation Practice", Evaluation and Program Planning, 22:1, pp. 105-111.

30. Swallow, B.M., D.P. Garrity and M. Van Noordwijk (2001) "The effect of Scales, Flows and Filters on Property Rights and Collective Action in Watershed Management”, CAPRi Working Paper No. 16, July, 2001.

31. UNDP (United Nations Development Programme) (1996a) “Aid Accountability Initiative”, Bi-Annual Report, 1 January-June 30, 1996, New York, July 1996.

32. UNDP (United Nations Development Programme) (1996b) "Capacity 21 Programme", Annual Report, Accessed 20 January 2000 <http://www3.undp.org/c21/reports/96.htm>

33. UNDP (United Nations Development Programme) (1997) "Corruption and Good Governance", Management Development and Governance Division, Discussion paper \#3, UNDP, New York, July 1997.

34. Weinberger, K. and J.P. Jütting (2001) Women's Participation in Local Organisations: Conditions and Constraints, World Development, 29:8, Elsevier Science Ltd., Great Britain, pp. 1391-1404.

35. World Bank (1996) "Civil Liberties, Democracy, and the Performance of Government Projects", World Bank, Policy Research Department, Poverty and Human Resources Division, Washington, D.C., 1996.

36. Yukl, G.A. (1981) "Leadership in Organisations", Prentice-Hall, Englewood Cliffs, N.J. 
Notes 